\title{
Pilot scale study on a new membrane bioreactor hybrid system in
}

\section{municipal wastewater treatment}

\author{
Tien Thanh Nguyen, Huu Hao Ngo ${ }^{*}$,Wenshan Guo \\ School of Civil and Environmental Engineering, University of Technology Sydney, \\ Broadway, NSW 2007, Australia \\ * Corresponding author, Tel: +61-2-9514-2745, Fax: + 61-2-9514-2633 \\ E-mail: $\underline{\text { h.ngo@uts.edu.au }}$
}

\begin{abstract}
A pilot scale membrane bioreactor hybrid system (MBR-HS) was evaluated for municipal wastewater treatment. This novel system comprised of a granular activated carbon - sponge fluidized bed bioreactor (GACS-FBBR) followed by a submerge membrane bioreactor (MBR) with the capacity of $2 \mathrm{~L}$ per minute. The results indicated that the MBR-HS could effectively remove $90 \%$ DOC and $95 \% \mathrm{NH}_{4}-\mathrm{N} . \mathrm{PO}_{4}-\mathrm{P}$ removal efficiency was remained stable at about $70 \%$ throughout the experiment. Specific oxygen uptake rate (SOUR) of activated sludge increased from 0.72 to $2.21 \mathrm{mg}$ $\mathrm{O}_{2} / \mathrm{gVSS}$.h for the first 10 days and then followed by a steady stage until the end of experiment. Sludge volume index (SVI) was always below $50 \mathrm{~mL} / \mathrm{g}$, demonstrated an excellent settling properties of sludge. The system also showed an achievement in terms of low trans-membrane pressure (TMP) development rate. The TMP increasing rate was only $0.65 \mathrm{kPa}$ / day, suggesting GACS-FBBR can be a promising pre-treatment for MBR.
\end{abstract}

Keywords: membrane bioreactor hybrid system, fluidized bed bioreactor, municipal wastewater, pilot scale 


\section{Introduction}

Membrane bioreactor (MBR) has been increasingly consolidating its status as a state-of-the-art technology in wastewater treatment during the last few decades.

Admittedly, this technology has several advantages over the conventional treatment systems, such as high treated water quality, less space requirement, and less sludge production. However, at the mean time MBR has an unavoidable obstacle which is difficult to overcome, namely membrane fouling (Guo et al., 2012). Membrane fouling reduces the membrane life, requires more energy for backwashing and makes the system less efficient. It is obvious that in practical application, assessing fouling mechanism with real wastewater and pilot scale system help further understanding of this topic as in several cases synthetic wastewater does not reflect genuine characteristics of the real one.

There has been recently enormous attention paid on examination of MBR performance in large scale. Most of recent studies indicated that treatment performance similar to that observed during bench-scale research may be obtained at a larger scale (Smith et al., 2012). Gao et al. (2009) developed a novel automatic vacuum MBR equipped with an on-line air-water-chemicals backwashing system for a purpose of the reclamation of domestic wastewater. The experimental setups were operated in pilot scale and experimental results indicated that membrane flux was able to resume as the fouled membrane modules being operated for 150 days. Compared to a new membrane module, the contaminated membrane fluxes were resumed to $94.7 \%$ after the first cleaning, to $82.7 \%$ after the second cleaning and to $70.0 \%$ after the third cleaning at a vacuum value of $20 \mathrm{kPa}$. To meet the standard of water reuse for car washing and land 
watering (PR China CJ25.1-89, COD concentration less than 30mg/L and ammonia nitrogen less than $10 \mathrm{mg} / \mathrm{L}$ ), the minimum HRT required by this system was $1 \mathrm{~h}$ for domestic wastewater reclamation. Lin et al. (2011) demonstrated that the submerged anaerobic MBR for municipal secondary wastewater treatment was technically feasible in terms of COD removal, sludge production and biogas yield. Membrane parameters, including flux, price and lifetime, played decisive roles in determining the total life cycle costs of the MBR system. The effectiveness of a full scale MBR in the removal of bacteriophages and bacterial fecal indicators from municipal wastewater was compared with that obtained by conventional activated sludge process (CASP) (De Luca et al., 2013). The MBR process was able to achieve respectively 2.7 and $1.7 \log 10$ higher reductions of somatic coliphages and F-RNA specific bacteriophages compared with CASP. In the meantime, the recent developments made in MBR have enhanced the performance of MBR, such as anaerobic MBRs using the Anammox process for nitrogen removal (Stuckey, 2012) and staged anaerobic fluidized MBR system for minimizing membrane fouling (Yoo et al. 2012).

Use of GAC in FBBR (GAC-FBBR) is an emerging technology for refractory organic pollutants removal, which was operated under anaerobic conditions (Xing et al., 2010). The GAC provides a temporary storage place, through adsorption, for occasions when the contaminant concentration is in excess of the bacterial capacity to transform. The contaminant then desorbs when concentrations decrease, maintaining the feed of the contaminant to the bacteria. GAC-FBBRs have also been used for treatment of coal gasification wastewaters and chlorinated solvents at the laboratory scale (Vidic et al., 1990). Initial studies of the GAC-FBBR were focused on the treatment of 
dinitrotoluene (DNT) in propellant wastewater. A bench scale study in a university laboratory, using synthetic wastewater, was undertaken to evaluate this technology for use in the field. The GAC-FBBR has also been evaluated in the laboratory environment for TNT degradation. A small scale system demonstrated that TNT could also be degraded (VanderLoop et al., 1999). The system was operated with ethanol as the electron donor and at constant influent concentrations. Biological GAC-FBBR has been shown to have the ability to remove the gasoline contamination from groundwater and provide both the efficiency of biological removal and the positive effluent protection capability of activated carbon adsorption.

Laboratory scale membrane bioreactor hybrid system (MBR-HS) was experimented in Environmental Engineering Laboratory, University of Technology, Sydney. The system included FBBR and sponge bioreactor followed by MBR (Nguyen et al., 2012). This system was successful in terms of organic and nutrient removal and reducing membrane fouling. By the end of 2010, a pilot scale MBR-HS was started and set up at the Water Reclamation Plant in Sydney Olympic Park. After the successful completion of the 2000 Olympic, Sydney Olympic Park Authority has undergone a significant amount of development work to support its conversion to a multipurpose facility with a number of businesses re-locating to the area. The collected domestic wastewater comes from sport arenas, office buildings, restaurants, hotels, and apartments in this area. The characteristics of the wastewater from the Water Reclamation Plant are quite different from synthetic wastewater used for laboratory scale experiments. 
The objective of this study is to investigate the performance of MBR hybrid system on treating municipal wastewater in SOP under the assessment of the following parameter: (i) the removal efficiency of organics and nutrients; (ii) the relation of mixed liquor suspended solid (MLSS) and sludge volume index (SVI); (iii) specific oxygen uptake rate; and (iv) trans-membrane pressure (TMP) development.

\section{Materials and methods}

\subsection{Municipal wastewaters}

The municipal wastewater used in this experiment was derived from Sydney Olympic Park. The wastewater had dissolved organic carbon (DOC) of 60-120 mg/L, COD of 271-385 mg/L, BOD ${ }_{5}$ of 133-193mg/L and suspended solids of 116-182 mg/L. The wastewater also contained high ammonia- $\mathrm{N}\left(\mathrm{NH}_{4}-\mathrm{N}\right)$ and orthophosphate $\left(\mathrm{PO}_{4}-\mathrm{P}\right)$ concentration of 21.4-51.2 $\mathrm{mg} / \mathrm{L}$ and $3.7-6.4 \mathrm{mg} / \mathrm{L}$, respectively. The $\mathrm{pH}$ of the wastewater was 7.44-7.52.

\subsection{MBR-HS description}

Influent wastewater from Wastewater Reclamation Treatment Plant freely flowed into a 60L equalisation tank (Fig. 1). A fine screen of $2 \mathrm{~mm}$ was also placed on the way in order to completely retain the coarse solids found. Wastewater was then fed to the FBBR by a PTX 141 pump with the constant flow rate of $2 \mathrm{~L} / \mathrm{min}$. The FBBR was made of acrylic with an internal diameter of $19 \mathrm{~cm}$, and $240 \mathrm{~cm}$ in height. About 22 L of GAC was filled in the FBBR. The coal based GAC (ACTICARB GS1300, Activated Carbon Technologies Pty Ltd., Australia) was used in this study. This coal 
based GAC has a surface area of $>1100 \mathrm{BETm}^{2} / \mathrm{g}$, an iodine number of $>1100 \mathrm{mg} /(\mathrm{g}$ min) and maximum ash content of $10 \%$. The height of GAC in the FBBR column was about $60 \mathrm{~cm}$, and its height expanded approximately 20\% with the upflow velocity of 37 $\mathrm{cm} / \mathrm{min}$. Wastewater from the FBBR was continually transferred into a sponge bioreactor. This reactor had dimension of $100 \times 60 \times 80 \mathrm{~cm}$, with the working volume of 330 L. S28-30/90R polyurethane sponge cubs was added to the reactor with the fraction volume of $10 \%$. Compressed air was used to supply oxygen and maintain the aerobic condition of the sponge bioreactor. Recirculation tank was placed after the sponge bioreactor in order to circulate wastewater back to the FBBR. $40 \mathrm{~L} / \mathrm{min}(95 \%)$ of the wastewater was returned in this stage from the recirculation tank. To keep the recirculated wastewater under the anaerobic condition, nitrogen gas was unendingly provided into the bottom of the recirculation tank, through several air stones. Effluent water of the system was drawn from sponge bioreactor.The FBBR had hydraulic retention time (HRT) of $2.5 \mathrm{~h}$ and organic loading rate (OLR) of 780-1100 gCOD/day. Membrane bioreactor was prepared for highly extended treatment for pre-treated water from the FBBR. The seed sludge for MBR was taken from the sequencing batch reactor at Water Reclamation Plant in Sydney Olympic Park and was acclimatized before starting the experiment. The reactor was made of acrylic with the working volume of 15 L. A flat sheet PVDF membrane with surface area of $0.2 \mathrm{~m}^{2}$ and pore size of $0.14 \mu \mathrm{m}$ was used in this experiment. The pre-treated water from the FBBR was collected and transferred into a $60 \mathrm{~L}$ feeding tank prior to the MBR. The experiment was conducted with activated sludge concentration of $5 \mathrm{~g} / \mathrm{L}$. The MBR was operated at flux of 10 $\mathrm{L} / \mathrm{m}^{2}$.h, backwash was applied one time per day ( 2 min duration) using filtrate with the backwash rate of $30 \mathrm{~L} / \mathrm{m}^{2}$.h. Pressure transducer with online data acquisition was used 
to monitor the TMP. A soaker hose air diffuser was used to maintain the air flow rate. The fouled membrane was physically cleaned after each stage prior to the next stage of the experiment.

Fig. 1. Experimental set up for the pilot scale MBR-HS experiment

\subsection{Analysis}

DOC of the influent and effluent was measured using the Analytikjena Multi $\mathrm{N} / \mathrm{C} 3100 . \mathrm{NO}_{2}-\mathrm{N}, \mathrm{NO}_{3}-\mathrm{N}, \mathrm{NH}_{4}-\mathrm{N}$, and $\mathrm{PO}_{4}-\mathrm{P}$ were measured by photometric method using Spectroquant ${ }^{\circledR}$ Cell Test (NOVA 60, Merck). The measuring of mixed liquor suspended solid (MLSS)and mixed liquor volatile suspended solids (MLVSS) wascarried out according to Standard Methods (APHA, 1998). YSI 5300 Biological Oxygen Monitor was used to measure the SOUR. The oxygen consumption measurement can be achieved through the use of oxygen electrode with oxygen permeable Teflon membrane. Voltage generated from the reaction is proportional to the oxygen concentration of the sample and produces oxygen uptake during a period of 2$15 \min$.

\section{Results and discussion}

\section{1. $p H, D O$, and $O R P$}

Fig. 2 presents the $\mathrm{pH}, \mathrm{ORP}$, and DO of influent wastewater, sponge tank, and recirculation tank of the membrane bioreactor hybrid system. $\mathrm{pH}$ value of the system showed that the influent $\mathrm{pH}$ wastewater varied from 7.4 to 8.2 during the whole experiment. The $\mathrm{pH}$ of sponge tank and recirculation showed the value of 7.0-7.4 and 7.4-7.7, respectively. The results also indicated that the ORP of influent wastewater was 
-30 to $-220 \mathrm{mV}$ and ORP of the sponge tank was positive, ranged between 50 to 200 $\mathrm{mV}$. However, the recirculation tank ORP was almost below $-50 \mathrm{mV}$, this was due to the supplying of nitrogen gas to maintain this reactor under the anaerobic condition. DO concentration of the influent wastewater was less than $0.5 \mathrm{mg} / \mathrm{L}$, indicating the low oxygen environment of the input. By supplying air continuously into the sponge tank, the DO of this reactor was maintained between 2.5 to $3.0 \mathrm{mg} / \mathrm{L}$. The DO concentration of the recirculation was also controlled under $0.5 \mathrm{mg} / \mathrm{L}$ by providing nitrogen gas all the time.

Fig. 2. pH, DO, ORP of influent, sponge tank, and recirculation tank of the pilot scale MBR-HS

\subsection{Organic and nutrient removal}

Fig. 3 presents the organic, $\mathrm{NH}_{4}-\mathrm{N}$ and $\mathrm{PO}_{4}-\mathrm{P}$ removal of the pilot scale MBRHS. DOC removal efficiency was $80 \%$ at the beginning of the experiment and gradually increased to $90 \%$ after 7 days of operation. It was followed by a steady stage with the removal efficiency of $92 \%$ till the end of the experiment. The results also showed the successful achievement in terms of $\mathrm{NH}_{4}-\mathrm{N}$ removal. It started with $85 \%$ removal at the first day and increased sharply to $95 \%$ just after 3 days of the experiment. The highest $\mathrm{NH}_{4}-\mathrm{N}$ removal efficiency was observed at $95.8 \%$ in 5 th day. It was gradually decreased to $90 \%$ after 20 days of operation and slumped to $82.5 \%$ at the end of the experiment. $\mathrm{PO}_{4}-\mathrm{P}$ results showed $46 \%$ removal at the beginning of the experiment. It was increasing slowly, peaked $70 \%$ at day 17 th. Thus, the GACS-FBBR could achieve high removal regarding DOC and $\mathrm{NH}_{4}-\mathrm{N}$. Zhang et al. (2012) investigated a submerged MBR with PVC hollow fiber membrane to treat municipal wastewater. The results showed that better removals of the main pollutants (90\% CODCr and $\left.92 \% \mathrm{NH}_{4}-\mathrm{N}\right)$. 
Qiu at el. (2013) developed a lab-scale upflow anaerobic sludge blanket (UASB)-MBR process for berberine removal from synthetic wastewater. The performance of the UASB-MBR system on berberine, $\mathrm{COD}$ and $\mathrm{NH}_{4}-\mathrm{N}$ removal was investigated at different berberine loadings. The overall removal rates of berberine, $\mathrm{COD}$ and $\mathrm{NH}_{4}-\mathrm{N}$ consistently reached up to $99 \%, 98 \%$ and $98 \%$, respectively.

Fig. 3. Organic and nutrient removal of the pilot scale MBR-HS

More specifically, the GAC-FBBR contributed $60-65 \%$ of DOC removal toward the total removal efficiency of the system, and the rest removed by MBR. Additionally, the GAC-FBBR alone achieved $55 \%$ of $\mathrm{NH}_{4}-\mathrm{N}$ and $40 \%$ of $\mathrm{PO}_{4}-\mathrm{P}$ removal before further removed by the MBR. The previous study also found an integrated fluidised bed bioreactor achieved $90 \%$ of DOC, $50-60 \%$ of T-N and T-P removal from primary treated sewage effluent (Xing et al., 2011). The relatively low phosphate removal in the system dues to the fact that municipal wastewater contains a large proportion of polyphosphates. Polyphosphates undergo hydrolysis in aqueous solutions and revert to the orthophosphate forms, which are available for biological metabolism without further breakdown; however, this hydrolysis is usually quite slow. Nitrification process has been examined in sponge bioreactor (SBR). The DO concentration of this reactor was always kept between $2.5-3 \mathrm{mg} / \mathrm{L}$. In theory, the nitrification rate should not improve above $2 \mathrm{mg} / \mathrm{L}$ of DO. Influent $\mathrm{NH}_{4}-\mathrm{N}$ of the SBR was $55.1 \pm 4.2 \mathrm{mg} / \mathrm{L}$ and effluent was $24.1 \pm 3.7 \mathrm{mg} / \mathrm{L}$. The SBR yielded $89.3 \mathrm{gN} /$ day of specific nitrification rate.

\subsection{Sludge SOUR}

The results of sludge SOUR indicated that microbial activity of activated sludge was increased during first 10 days, started from $0.72 \mathrm{mg} \mathrm{O} / \mathrm{gVSS}$.h at the first day and 
reached the maximum point of $2.21 \mathrm{mg} \mathrm{O} / \mathrm{gVSS}$.h at day 10th. It was followed by a slump to $1.92 \mathrm{mg} \mathrm{O} / \mathrm{gVSS}$.h and then remained stable until the end of the experiment. This result indicated that microbial activity was developing during first 10 days and followed by a steady stage till the day 25 of the experiment.

\subsection{MLSS and SVI}

Fig. 4 shows the MLSS and SVI of the activated sludge of the MBR-HS. The experiment was started with $5.2 \mathrm{~g} / \mathrm{L}$ MLSS and $4.45 \mathrm{~g} / \mathrm{L}$ MLVSS. Biomass concentration of the MBR was increasing as no sludge withdrawn took place. MLSS concentration increased with the rate of $64 \mathrm{mg} / \mathrm{day}$, ended at $6.8 \mathrm{~g} / \mathrm{L}$ after 25 days of operation. The development rate of MLVSS was a bit slower with the rate of $34 \mathrm{mg} / \mathrm{L}$. At the end of the experiment, the MLVSS concentration was $5.0 \mathrm{~g} / \mathrm{L}$, increased $32.5 \%$ as compared to the beginning of the experiment. SVI value of activated sludge was also proportional to the increasing of the biomass in the reactor. It was about $10 \mathrm{~mL} / \mathrm{g}$ during the first 5 days of the experiment, and between $20-30 \mathrm{mg} / \mathrm{L}$ from day 7 to 15 , and continually increased to $43 \mathrm{~mL} / \mathrm{g}$ after 25 days of operation. In this present study, SVI value was always below $100 \mathrm{~mL} / \mathrm{g}$, indicating good settling properties of the sludge. High SVI is normally attributed to the growth of filamentous bacteria which negatively effects the characteristics of the activated sludge.

Fig. 4. MLSS and SVI of the activated sludge of the MBR-HS

\subsection{TMP development}

TMP development of the MBR-HS was measured daily in this experiment. The increasing of TMP in this experiment can be divided into two parts, the first 17 days and from day 17 th to the end of the operation. TMP was $3.25 \mathrm{kPa}$ at the first day of the experiment and was gradually increasing to $14.35 \mathrm{kPa}$ at day $17^{\text {th }}$. The TMP 
development rate at this stage was $0.65 \mathrm{kPa} /$ day. Nevertheless, the TMP increased dramatically in the second stage with the development rate of $4.04 \mathrm{kPa} / \mathrm{day}$. It was 48 $\mathrm{kPa}$ at the end of the experiment. This TMP development rate was relatively low compared to previous study of Shan et al. (2012), achieved of about $10 \mathrm{kPa} /$ day at HRT of $1 \mathrm{hr}$. This result indicated the membrane was fouled severely after 17 days of operation. This could be explained by the less frequency of backwash for the membrane (only once per day for $2 \mathrm{~min}$ ).

\section{Conclusions}

The pilot-scale FBBR-MBR hybrid system could remove more than $95 \%$ of organic carbon and $\mathrm{NH}_{4}-\mathrm{N}$, and more than $70 \%$ of $\mathrm{PO}_{4}-\mathrm{P}$ when treating municipal wastewater. Microbial activity of the sludge of the FBBR-MBR hybrid system gradually increased during the first 10 days of the experiment, reached the peak of 2.21 mg $\mathrm{O}_{2} / \mathrm{gVSS}$.h, and followed by a steady stage. SVI was always below $100 \mathrm{~mL} / \mathrm{g}$, indicating the good settling property of activated sludge. The hybrid system was successful in mitigating the membrane fouling as the TMP development of only 0.65 $\mathrm{kPa} / \mathrm{day}$.

\section{Acknowledgment}

This study was funded by Australian Research Council (ARC) Industry Linkage Grant (LP0882089). 


\section{References}

1. APHA, AWWA, and WEF, 1998.Standard Methods for the examination of Water and Wastewater, $20^{\text {th }}$ edition.American Public Health Association, Washington, DC.

2. De Luca, G., Sacchetti, R., Leoni, E., Zanetti F.,

2013. Removal of indicator bacteriophages from municipal wastewater by a fullscale membrane bioreactor and a conventional activated sludge process:

Implications to water reuse. Bioresource Technology 129, 526-531.

3. Gao, M.Z., Chen, Z.B., Ren, N.Q., Zhang, Z.P., 2009. A novel application of automatic vacuum membrane bioreactor in wastewater reclamation. Desalination 247, 583-593.

4. Guo, W.S., Ngo, H.H., Li, J.X., (2012). A minireview on membrane fouling. Bioresource Technology 122, 27-34.

5. Lin, H.J., Chen, J.R., Wang, F.Y., Ding, L.X., Hong, H.C., 2011. Feasibility evaluation of submerged anaerobic membrane bioreactor for municipal secondary wastewater treatment. Desalination 280, 120126.

6. Nguyen, T.T., Ngo, H.H, Guo, W.S., Listowski, A., Li, J.X., 2012. Evaluation of sponge tray-membrane bioreactor (ST-MBR) for primary treated sewage effluent treatment. Bioresource Technology 113, 143-147.

7. Qiu, G., Song, Y., Zeng, P., Duan, L., Xiao S., 2013. Combination of upflow anaerobic sludge blanket (UASB) and membrane bioreactor (MBR) for berberine reduction from wastewater and the effects of 
berberine on bacterial community dynamics. Journal of Hazardous Materials $246-247,34-43$.

8 .

Shan, H., Rupak, A., Vigneswaran, S., Johir,

M.A.H., Kandasamy, J., 2012. Influence of hydraulic retention time on the nature of foulant organics in a high rate membrane bioreactor. Desalination 287, 116-122.

9. Smith, A.L., Stadler, L.B., Love, N.G., Skerlos, S.J., Raskin, L., 2012.

Perspectives on anaerobic membrane bioreactor treatment of domestic wastewater: A critical review. Bioresource Technology 122, 149-159.

10. Stuckey, D.C. 2012. Recent developments in anaerobic membrane reactors. Bioresource Technology 122, 137-148.

11. VanderLoop, S. L., Suidan, M. T., 1999. Biotransformation of 2,4-dinitrotoluene under different electron acceptor conditions. Water Research 33, 1287-1295.

12. Vidic, R. D., Suidan, M. T., 1990. Adsorption isotherms: illusive capacity and role of oxygen. Water Research 24, 1187-1195.

13. Xing, W., Ngo, H.H., Guo, W.S., Wu, Z.Q., Nguyen, T.T., Cullum, P., Listowski, A., Yang N., (2010). Enhancement of the performance of anaerobic fluidized bed bioreactors (AFBBRs) by a new starch based flocculant, Separation and Purification Technology 72(2), 140-146.

14. Xing, W., Ngo, H.H., Guo, W.S., Listowski, A., Cullum, P., 2011. Evaluation of an integrated sponge - Granular activated carbon fluidized bed bioreactor for treating primary treated sewage effluent. Bioresource Technology 102, 54485453. 
15. Yoo, R., Kim, J., McCarty, P.L., Bae, J., 2012. Anaerobic treatment of municipal wastewater with a staged anaerobic fluidized membrane bioreactor (SAF-MBR) system. Bioresource Technology 120, 133-139.

16. Zhang, Y.H., Wang, M., Guo, Z.Y., Shen, J., Zhang, Z.B., Xing, L.Z., Li, L., 2013. Study on Municipal Wastewater Treatment by a Submerged Membrane Bioreactor. Advanced Materials Research 610-613, 1487-1490. 


\section{FIGURE CAPTIONS}

Fig. 1. Experimental set up for the pilot scale MBR-HS experiment

Fig. 2. $\mathrm{pH}, \mathrm{DO}, \mathrm{ORP}$ of influent, sponge tank, and recirculation tank of the pilot scale MBR-HS

Fig. 3. Organic and nutrient removal of the pilot scale MBR-HS

Fig. 4. MLSS and SVI of the activated sludge of the MBR-HS 

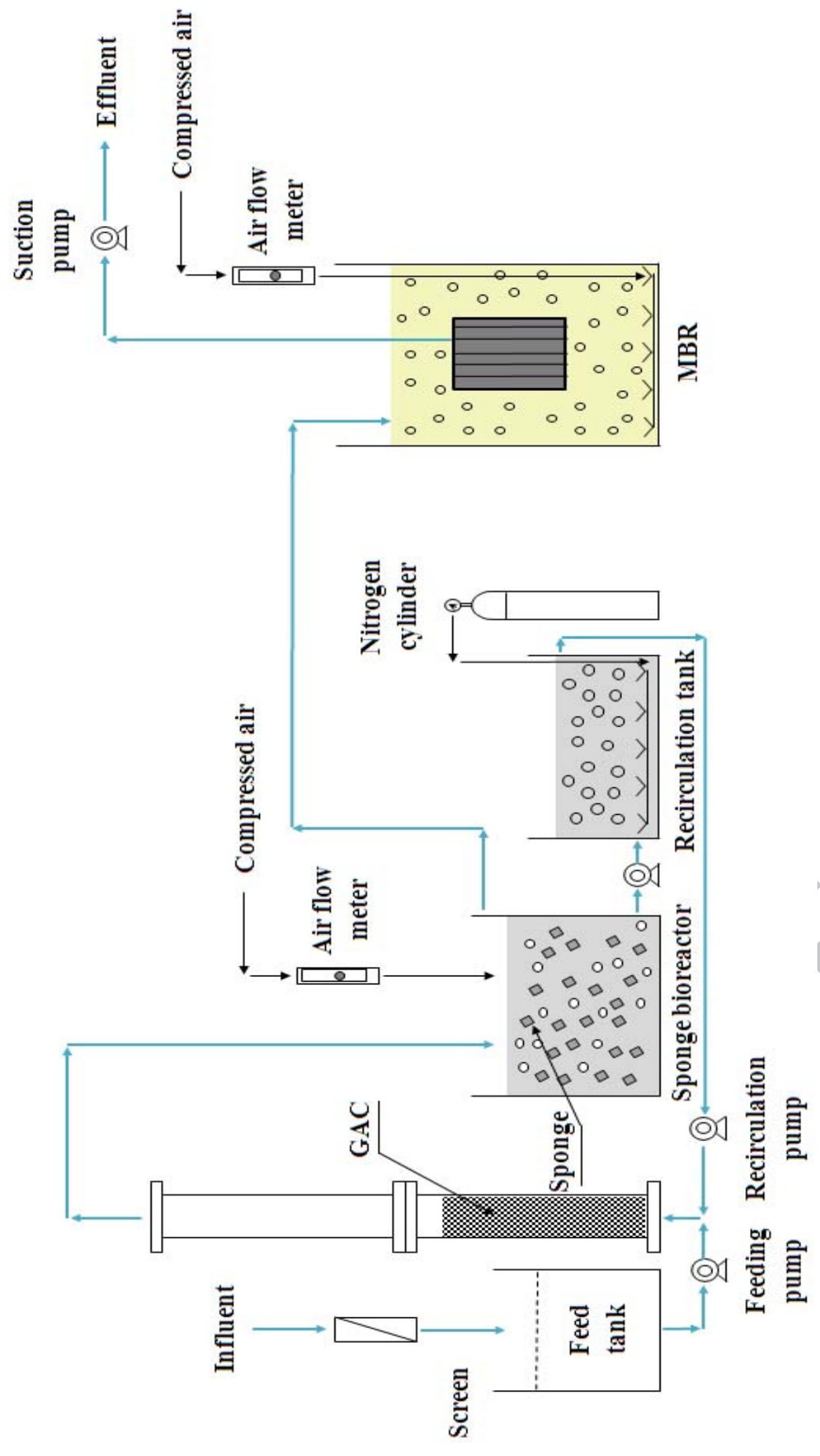

6

لت 

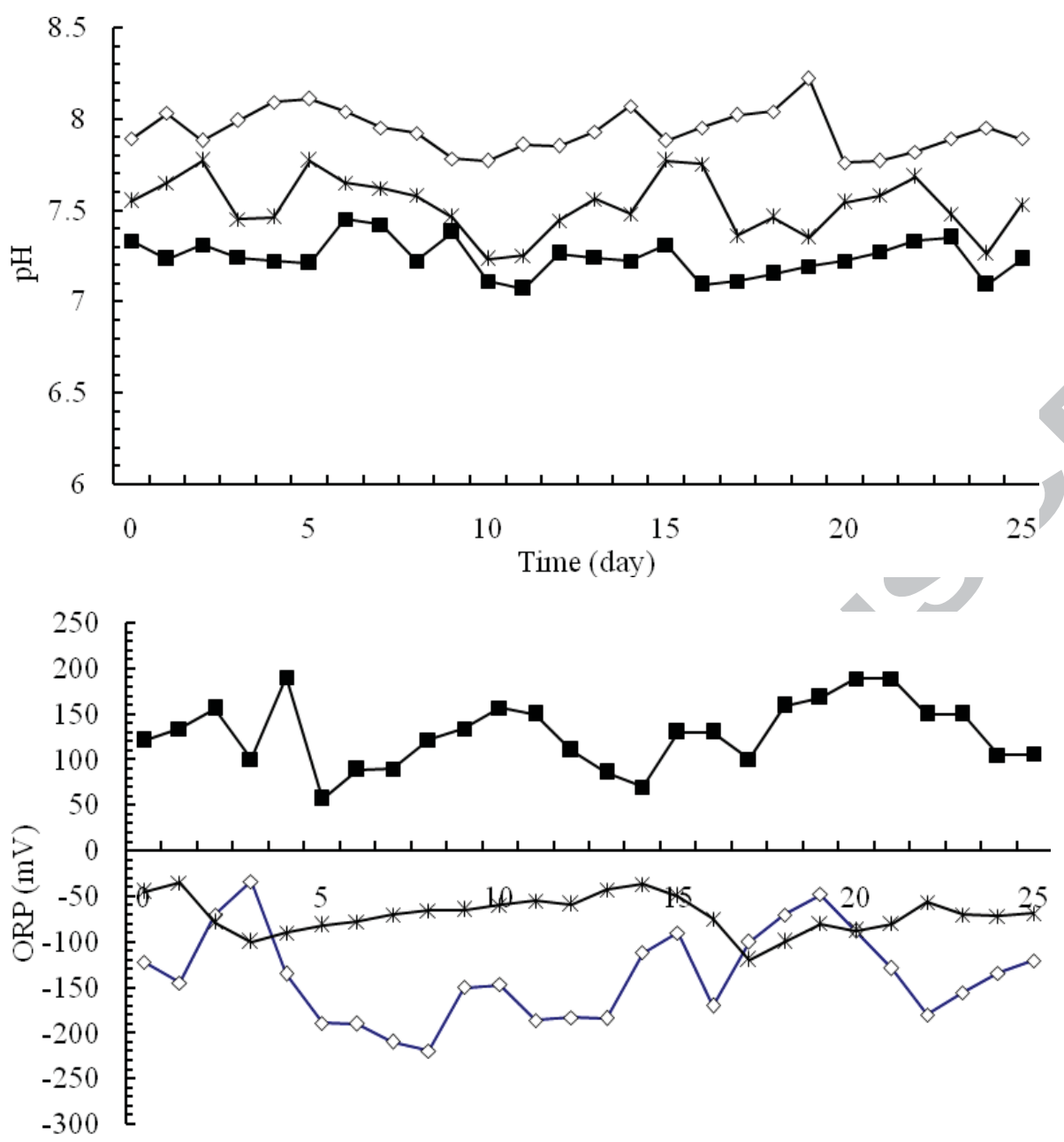

Time (day)

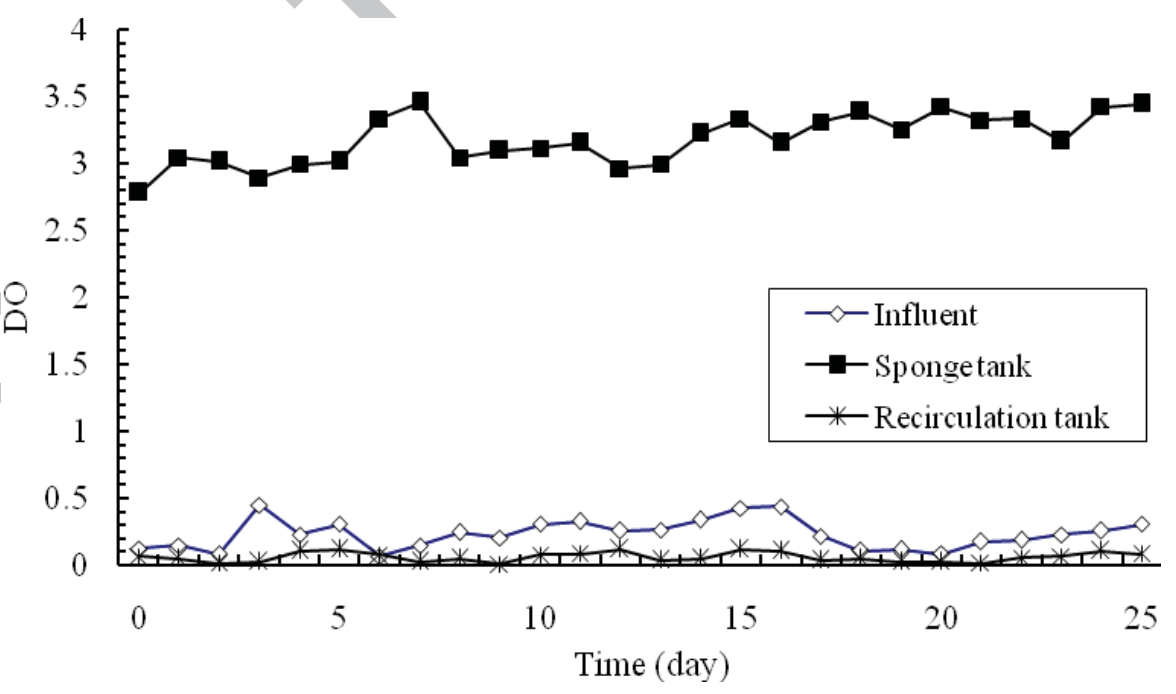

Figure 2 


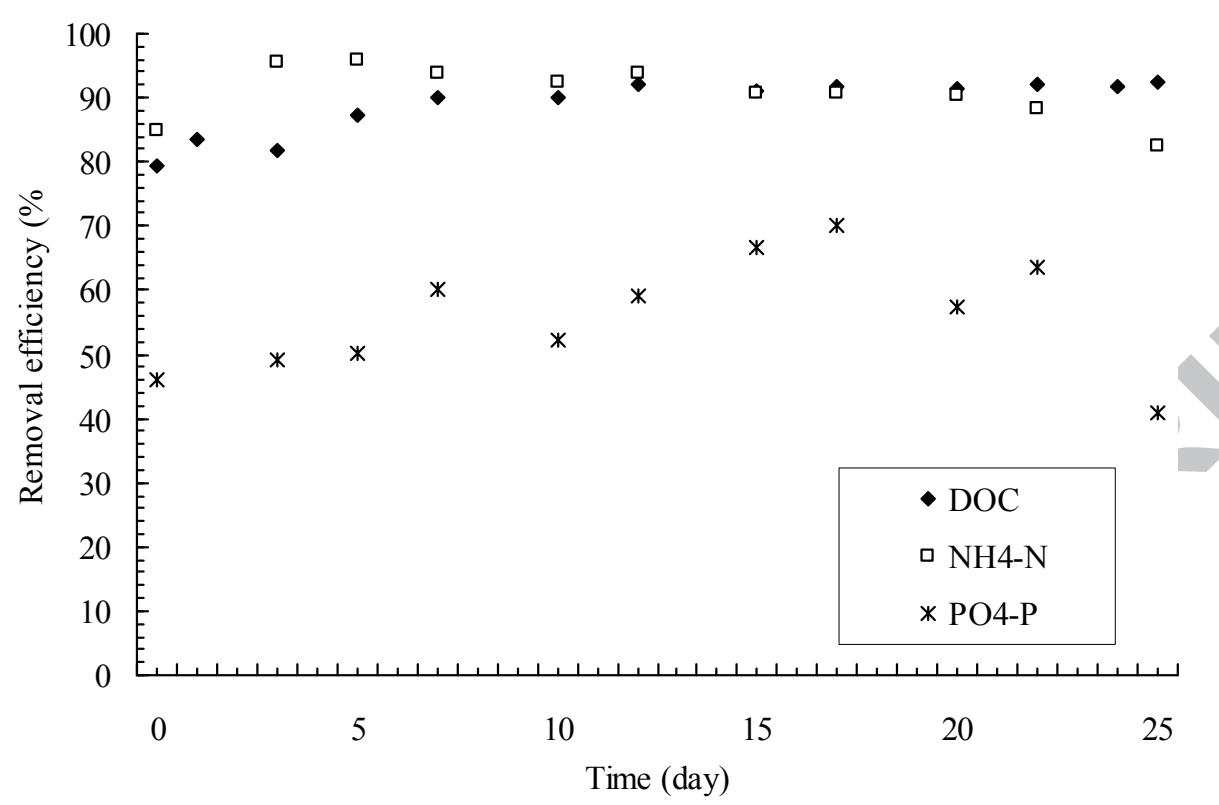

Figure 3 


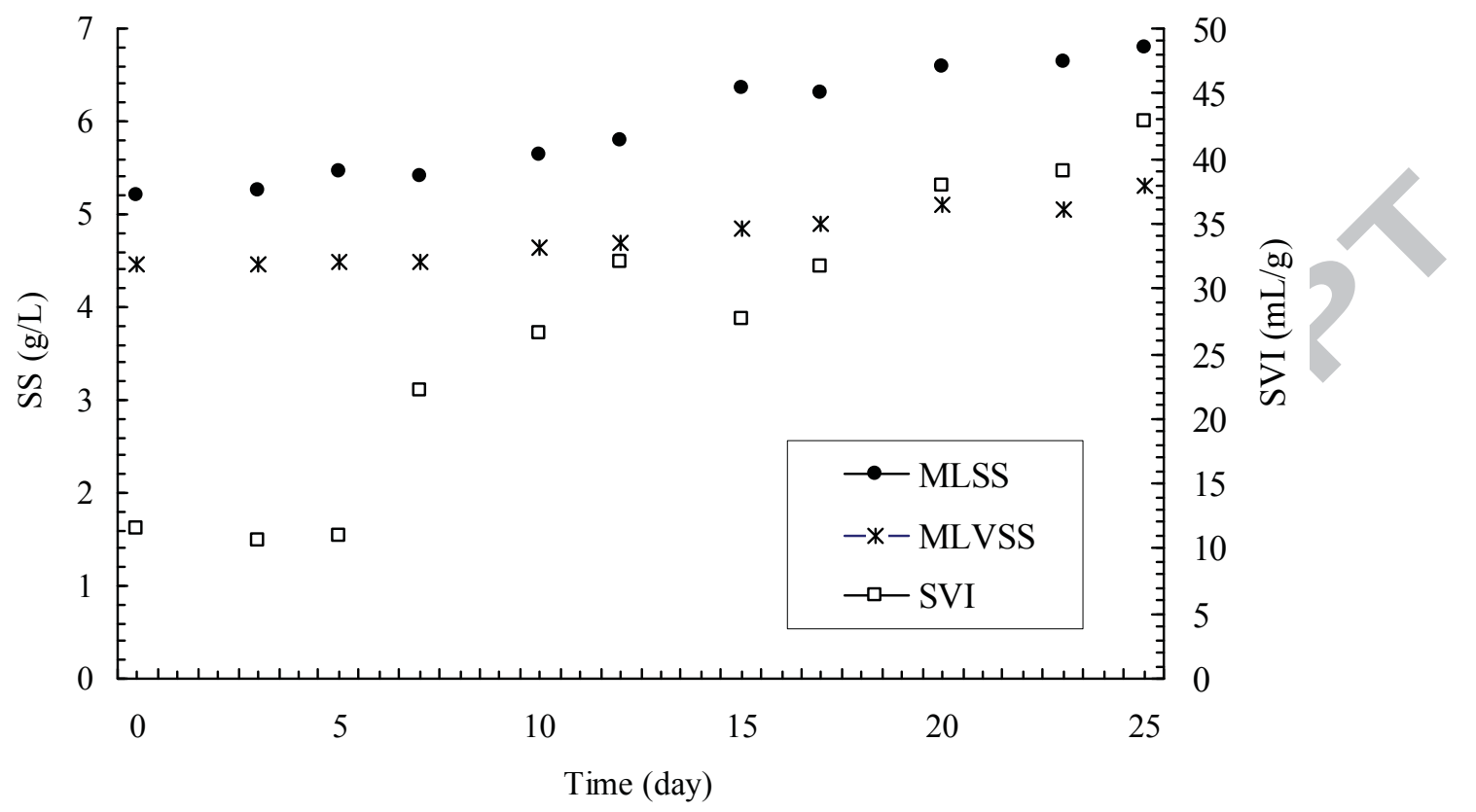

Figure 4 
HIGHLIGHTS

- The pilot scale GACS-FBBR-MBR was successful in treating municipal wastewater.

- GACS-FBBR is a promising pre-treatment method for membrane bioreactor.

- SVI was below $100 \mathrm{~mL} / \mathrm{g}$, indicating the good settling property of activated sludge.

- The hybrid system was successful in mitigating membrane fouling. 